\title{
Migration in Denpasar City: Study of Adaptation Strategy and Its Implication of Social Culture and Environment
}

\author{
A.A. Ngurah Anom Kumbara ${ }^{1}$ and A.A. Sagung Kartika Dewi ${ }^{2}$ \\ ${ }^{1}$ Faculty of Arts \\ Udayana University \\ Bali, Indonesia \\ anom_kumbara@yahoo.unud.ac.id \\ ${ }^{2}$ Faculty of Economic and Business \\ Udayana University \\ Bali, Indonesia \\ sagungkartika@yahoo.com
}

\begin{abstract}
Denpasar City, both as the capital of Bali as well as the center of trade, education, and tourism destinations. This potential is a strong attraction for the migrants to come and settle in Denpasar City. The purposes of this study are: 1) to get an overview of the characteristics of the migrants; 2) understanding the pattern of migrant adaptation; and 3) to analyze its implications of socio-cultural and environment. The approach method used is descriptive qualitative. Data collection used through structured interviews, observation, and Focus Group Discussion. Based on the analysis, this study found that the average age of migrants classified as productive, is in the range 30-40 years. The level of education of migrants is quite good, mostly high school and even some university grade. The pattern of adaptation that is done tends to choose clustered residence based on the similarity of ethnic and religion background. The socio-cultural implications have not been so apparent, that local cultures are still dominant. The implications for the environment appear to be quite significant, which is marked by the increasing number of land conversion for various designations. The emergence of slums and semi-permanent settlements built to meet the needs of many migrants throughout the sub district in Denpasar. This condition then injured the icon of Denpasar as a cultural city. Beside that, the quality of environments and raw water of the population has decreased, caused due of domestic household waste and wastewater of the garment industry and laundry services.
\end{abstract}

Keywords: migration, full and push factor, adaptation, social culture

\section{INTRODUCTION}

Denpasar City has become a multi-ethnic, multicultural and multi-cultural city along with the opening of Denpasar as the destination of migration of people from various regions in Indonesia. According to statistical data, Denpasar population flow of migrants into Denpasar has increased significantly from year to year. Theoretically, migration phenomenon arises because two main factors are push factor and pull factor (full factor).

Denpasar, both as the capital of Bali and as one of the tourist destinations in Bali has the potential of relatively larger development resources and the provision of wider employment is expected to be the main attraction of migration. On the other hand, the inequality of interregional development and limited employment in the place of origin is one of the driving factors.

The high flow of migration in Denpasar will not only cause population problems, but also social and cultural issues. The formation of a multiethnic, multicultural, and multi-religious society has the potential of social disharmony. Given the higher the heterogeneity of a society, the greater the chance of disharmony and social conflict. On the other hand, the presence of immigrant populations in big cities often creates complex and complex issues especially with regard to social changes in urban environments. However, disharmony and social conflicts should not be allowed to occur and solutions must be found. 
Based on this background, the purpose of this research is to understand the characteristics of non-Bali migrants in Denpasar; (2) understand migrant adaptation strategies, and 3) analyze their implications on socio-cultural and environmental issues.

\section{CONCEPTS AND THEORIES}

The word "migration" in Big Indonesian Dictionary (2005: 742) means the migration of people from one place to another to settle. There are types of migration, among others (a) inter-village migration is the movement of the population from one village to another; (b) intercity migration is the movement of the population from one city to another; (c) chain migration is the movement of the population from one region to another, followed by the resident of its origin, occurs when the first group or person succeeds and draws family, friends, or neighbors from their home region; (d) seasonal migration is the movement of the population occurring in certain seasons and returning to the place of origin in another season; (e) rural-urban migration is a migration from rural to urban; (f) external migration is the movement of the population into the territory of another country; (g) internal migration is the movement of the population taking place in the territory of a country; (h) urban-village migration is the movement of the population from town to village; and (i) forced migration is a forced migration, for example due to chaos and natural disasters that are forced to move to other areas

The conception or notion of migration shows dynamic meanings and traits. Migration can occur due to various factors that are push (push) and pull (full) so that people move from one place to another. according to Garna (1992: 98) that migration occurs because of inequality or inequality of sources of fulfillment of life needs between one region with another. That is, the movement of people from one region to another is not a natural process, but because of certain motivations and goals. Therefore, migration will always give rise to various social and ecological implications because the motives and goals of migrants also vary. Thus, the meaning of migration in this study is the migration of non-Bali population from outside the region to stay settled in Denpasar in a relatively long time with a specific purpose motive.

\section{Cultural Adaptation in the context of Migration}

Adaptation is a concept derived from cultural ecology. According to Steward (Poerwanto, 2010: 68) that cultural ecology is the study of how humans as living beings adapt themselves to certain geographical environments. Included in key concepts of cultural ecology are adaptation, system, and environment. Meanwhile, Kaplan and Manners (2002: 112) state that adaptation is a process that links the cultural and environmental systems. In line with that, Daeng (2008: 44) also states that adaptation is an adjustment between the organism and its environment as a whole in which the environment becomes part of it.

Meanwhile, Hardestry (1977: 45-46) states that adaptation is a dynamic process, because neither man nor environment are constant or fixed. Population survival is not passive towards the environment, but provides the space for individuals and populations to work actively to modify their behaviors in order to maintain certain conditions, cope with risks to new conditions, and improvise existing conditions. In this regard, Kaplan and Manners (2002: 116) argue that humans adapt to cultural mechanisms, which are typical human ways of dealing with the necessities of different places and times

According to Sanderson (2003: 68) that adaptation is a social trait (nature or social behavior) that arises as a result of the needs, goals, and desires of individuals. Adaptation is closely related to a sociocultural pattern, because new sociocultural forms emerge from the adaptation process. Sanderson (2003: 72) also added that sociocultural innovation is done intentionally and not randomly so that sociocultural evolution takes place very quickly. In this case, adaptation is seen as a process of making space changes in which there is cultural behavior, which is technological, organizational, and ideological (Hardestry, 1977: 243). This theory asserts that cultural adaptation is a society's ability to maintain its life and culture. This process of adaptation is characterized by an increase in adaptive upgrading (Parsons, 1971: 27) or adaptive modification (Sahlins, 1960: 2). Adaptation is not solely determined by the desires, needs, and objectives derived from culture as a system of knowledge, but also determined by the local environmental situation (Bennet, 1976: 257). In this case, cultural adaptation involves the role of agents and structures dialectically. That is, agents have the freedom to choose adaptive strategies, but they can only be executed through structural social practices. Thus, the theory of cultural adaptation explains the reasons individuals and groups adapt, as well as the emerging forms of adaptation.

Based on that understanding, cultural adaptation is a cultural mechanism by individuals or social groups to adapt to the environment in which they live. In this research, cultural adaptation is used as a perspective to see the model of adaptation of migrant and indigenous population in Denpasar.

\section{RESEARCH METHODS}

The design of the study was designed using a qualitative approach. The subjects of the study were the migrants who were selected as respondents who lived in four subdistrict districts in Denpasar, which included the subdistricts of West, North, East and South Denpasar. The number of respondents interviewed was 40 persons who were chosen purposively incidental when they were met at their residence. The criteria used are willing to be interviewed and come from outside the region. To get a deeper understanding of the problem also used Focus Group Discussion (FGD) method combined with observation to respondents' environment. The study time is 4 months, from July to October 2017. 


\section{RESULTS AND DISCUSSION}

\section{A. Characteristics of Non-Bali Migrants in Denpasar Migrants by age, Gender, and Marital status}

In demography theory it is explained that population growth in a region is determined by three important factors: birth (nalitas), death (mortality), and migration (migration). These three variables also have a positive correlation with population density in a region. Artiya, the higher the birth rate, which is inversely proportional to the mortality rate causing population density in the region will increase. faster The intensity of out-of-population migration and entry in unequal regions affects the population density.

The intensity of migration is also related to the characteristics of subjects such as age, sex, marital status, distance and psychological factors and motivation. In this regard, Lee (in Munir 2000: 120) discloses four factors that influence people to make the decision to migrate: 1) factors in origin; 2) factors in the destination; 3) obstructing barriers, and 4) motivational / personal factors.

Figure 1 shown With respect to the characteristics of migrants in Denpasar City viewed in terms of age, that most respenden (86.37) are in the productive age category. otherwise only $13.63 \%$ belong to unproductive age. When seen the age range of respondents appear 20-29 years old the highest percentage $(34.09 \%)$. on the contrary the respondents aged under twenty years of the smallest percentage or only $(9.09 \%)$. If the characteristics of respondents seen in terms of marital status and gender it appears that more than half $(65.91 \%)$ categorized have been married and the rest $(34.09 \%)$ have not been married. This condition is reasonable considering that in the personal motivation relationship of migrating people is due to the reasons Economic. Culturally the husband has the primary responsibility or obligation as a breadwinner for his wife and children or family.

\section{Characteristics of migrants}

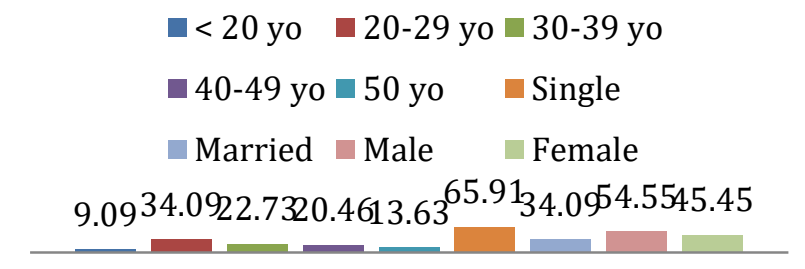

Fig. 1 Characteristics of Migrants

Respondents by Education Level and Employment Option.

In demographic theory, the level of education becomes an important indicator or variable that is often used to measure the existence of permanent residence for a long time in a region including migrant groups. Correlatively, the recognized level of employment education can affect and or relate to the chosen livelihood, productivity including income.

In relation to the statement related to the study focus on the characteristics of migrants in Denpasar according to the level of education and livelihoods, the survey results indicate that $45.45 \%$ of migrants / respondents in Denpasar City have graduated from senior high school and even graduated percentage and/or have studied at university quite high that is 18.18 percent. When these two education groups are combined there will be a pretty interesting picture where more than a few migrants from outside Bali are graduated with SLA and even some graduated and or have been at university. This condition is different from the general assumption that has been growing in Bali that most migrants who come and live in Denpasar are poorly educated and lack the necessary skills, so they are often labeled as the source of the problem.

Meanwhile, the characteristics of migrants as respondents who focused on the type of livelihoods involved in the survey results show that more than half $(56.82 \%)$ of migrants in Denpasar work in the entrepreneurial or commercial sector and only $22.73 \%$ of respondents work as laborers. A closer look at the data is linked to the general view or general perception of Balinese people that the presence of migrants in Bali mostly work as laborers is not entirely true. The real empirical picture based on the results of this survey shows that some of the respondents work in the entrepreneurial/commercial sector where the sector is clustered in the informal sector.

If this condition continues and the percentage rate of migrants in Denpasar working in the entrepreneurship sector continues to increase, then such conditions will be a serious problem for the local workforce in the future. This can be a serious problem when, on the one hand, the formal sector is no longer able to accommodate the growth of local manpower and on the other, the increasingly limited opportunities of the informal sector (trade/entrepreneurship) are already taken by non-Balinese migrants. Under such conditions, the local government should immediately take steps to anticipate and prevent the occurrence of massive unemployment in the local population. Otherwise, it is feared that conflicts between non-Bali migrants and local residents could be triggered by an increasingly limited seizure of space and employment.

Migrants by ethnicity, Origin of region, and Length of Stay

Characteristics of respondents in Denpasar based on ethnicity and/origin of the region, the survey results show that the characteristics of migrants in Denpasar based on ethnicity and area of origin did not show the difference in the number of outstanding percentages. The highest percentages are Javanese as much as (29.55\%), NTT (Ende, Sikka, and Lombok as much as 25\%), Sasak (18.18\%) and others $(27.27 \%)$. Thus, the presence of migrants in 
Denpasar in terms of ethnic differences percentage is not too significant or the number is relatively balanced.

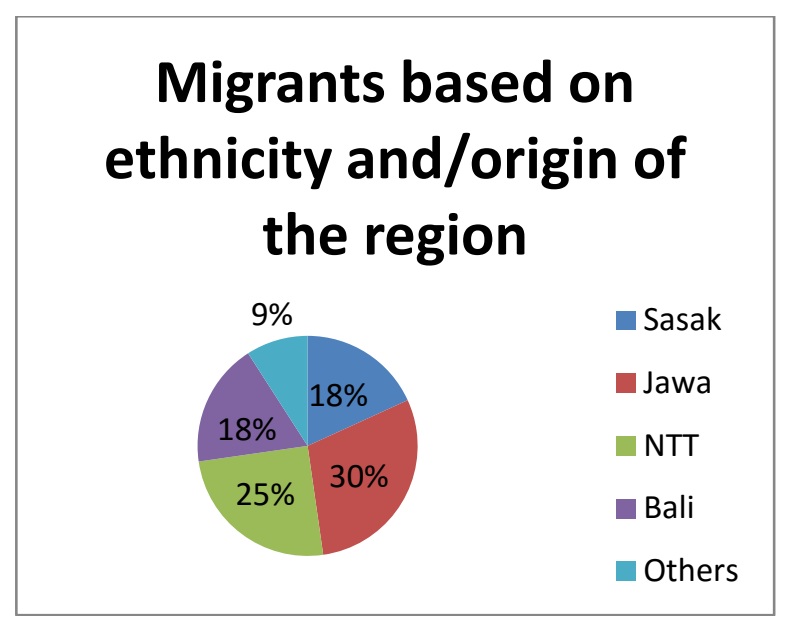

Fig. 2 Migrants based on ethnicity and/origin of the region

Respondent by reason of moving from area of origin

Population mobility geographically, sociologically, economically, even culture is necessity. Migration is one form of population mobility. Definitively migration is the migration of people from one place to another to settle. There are types of migration, among others (a) inter-village migration is the movement of the population from one village to another; (b) intercity migration is the movement of the population from one city to another; (c) chain migration is the movement of the population from one region to another, followed by the resident of its origin, occurs when the first group or person succeeds and draws family, friends, or neighbors from their home region; (d) seasonal migration is the movement of the population occurring in certain seasons and returning to the place of origin in another season; (e) rural-urban migration is a migration from rural to urban; (f) external migration is the movement of the population into the territory of another country; (g) internal migration is the movement of the population taking place in the territory of a country; (h) urban-village migration is the movement of the population from town to village; and (i) forced migration is a forced migration, for example due to chaos and natural disasters that are forced to move to other areas

The conception or notion of migration shows dynamic meanings and traits. Migration can occur due to various factors that are push (push factor) and full (full factor). According to Garna (1992: 98) that migration occurs because the inequality of sources of fulfillment of life needs between one area with another. That is, the movement of people from one region to another is not a natural process, but because of certain motivations and goals. Therefore, migration will always give rise to various social implications because the motives and goals of migrants also vary.

According to Lee (in Munir, 2000: 120) there are four factors that influence people to make the decision to migrate: 1) factors in the area of origin; 2) factors in the destination; 3) obstructing hurdles, and 4) personal factors. Based on that opinion, it is related to survey result about the reason or factor of the respondent/migrants moved from the area of origin to Denpasar, that is more $(65,91 \%)$ give reason because hard to find work in area of origin. This condition is very reasonable and in accordance with the theory of population which states that the main driving factors people move or leave the area of origin because of limited employment in the area of origin. In addition, economic infrastructure facilities, inadequate entertainment access in the area of origin is also an important reason for the move.

Respondents according to the reason chose Denpasar as the destination of migration

In migration theory it is stated that people moving from one residence to another can be influenced or driven by internal factor factors, such as safety and comfort levels, inadequate infrastructure facilities, limited field availability, and etc. Conversely, it can be driven by a positive external factor or fush factor that is thought to give new hope to migrants in the destination area. When a person chooses to migrate, there are also a number of obstacles to overcome, such as distance issues, family ties, traditions, customs, and population administration issues. Furthermore, experience factors, knowledge, objectives, intelligence and individual motives, such as the desire to develop a business in a potential destination area, become important decisionmaking factors. In relation to the explanation, the result of the survey on migrants in Denpasar obtained data, that most respondents $(65.91 \%)$ chose Denpasar as the destination of migration because of the reason in Denpasar there are many opportunities/jobs, which states Denpasar safe and comfortable as much as $15.91 \%$ and the reason the facility is adequate only 18.18 . Thus the main reason for migrating to Denpasar is to look for jobs or economic motives. Thus, the empirical reality derived from the results of this survey is actually no different from what is described in the demographic theory that developed so far, that is because of the availability of economic resources (employment), adequate infrastructure facilities, and security and comfort factor of a region to be a factor towing migration purpose.

\section{B. Strategy of Cultural Adaptation of Migrants in Denpasar}

Circular cultural adaptation suggests that the social environment, and the indigenous cultural patterns of Denpasar have had an effect on the re-arrangement of social structures and patterns of behavior of migrant populations. To clarify the form of adaptation by migrant residents to the indigenous cultural patterns in Denpasar, it is necessary to distinguish between the immigrant population who are Hindus and non-Hindus. This distinction is made in view of the indigenous cultural patterns centered on the implementation of Hinduism that animates other sociocultural activities. Therefore, the adaptation model of the immigrant population of Hindus certainly has different characteristics from the non-Hindu immigrant population. 
The inhabitants of Hindu origin are mainly from other districts in Bali and a few others from outside Bali. Culturally, the inhabitants of Hindu migrants have a cultural pattern that is not much different from the indigenous population, although the customs in each region does have differences according to the village, kala, patra. In general, the population of immigrants who are Hindus, especially ethnic Balinese, do not become customary krama because they have been recorded as customary krama in the area of origin. Nevertheless, there are also immigrant residents who choose to become customary krama in Denpasar with consequences out of banjar adat in their area of origin or have two custom status krama.

Meanwhile, non-Hindu immigrant settlers generally come from various areas outside Bali, such as Java, NTT, Lombok, and other areas. Religious and cultural differences are a challenge for non-Hindu immigrants to adapt to local cultural patterns. The migrant population is also faced with efforts to meet the needs of life and sustainability of the economic activities they undertake. Instead economic interests become the dominant adaptation motive so that non-Hindu immigrant population does not prioritize its involvement in socio-cultural activities in pakraman village. In other words, adaptation is done only to provide comfort and security of non-Hindu immigrant residents in work. However, long-term settlers in the city of Denpasar sometimes contribute to customary activities, such as donating to pakraman villages for diversity activities, such as buying gong, making ogoh-ogoh, and in the implementation of bazaar by sekaa taruna.

In addition to adaptation patterns as mentioned above, to obtain security and comfort of life respondents tend to choose places and live in groups in a region on the basis of consideration of the similarity of ethnic and regional origin as well as consideration of security and comfort. In this context, the survey results show that $86.36 \%$ of migrants live in the same ethnic group for reasons of comfort and security.

\section{Social and Cultural Implications}

In the context of socio-cultural environment, the intensity of migration from various regions in Indonesia, led to the formation of a multiethnic, multicultural, and multi-religious community in Denpasar. This condition has great potential as a source of social disharism. Given that, the higher the heterogeneity of a society, the greater the chance of disharmony and social conflict resulting from the conflict of interests. On the other hand, the presence of immigrant populations in big cities does often lead to complex and complex issues related primarily to lifestyle changes dimensions, increasing social pathology cases (drug abuse, prostitution and increasing cases of people infected with HIV/AIDS due to unhealthy behavior). In addition, the outflow of outside uncontrolled population has also resulted in an increase in the quantity and quality of crime in Denpasar.
Meanwhile, the impact of the increasing intensity of migration in Denpasar on the environment based on the results of the study obtained a picture of the physical environment conditions are quite severe and apprehensive. This condition occurs evenly in four districts in Denpasar. The forms of impact of migration to the environment in Denpasar are quite prominent is the proliferation of pockets of houses/slums from downtown to the periphery. The higher levels of environmental pollution, especially the quality of raw ground water used by residents due to waste and waste generated, both from daily dominant activity and household waste, such as from tahu-tempe companies, and garment business are removed to the river stream.

Another impact of migration on the environment is the high number of conversion of rice fields into residential areas, rented houses, shops, and facilities for tourism causes the availability of green open areas is increasingly depleted. In addition, more water for the rice fields of the closed population due to the construction of these facilities, then resulted in the transfer of wetland to moor land also more and more. According to Denpasar Statistics Data In Figures Year 2013, during the three years running 2009-2011 there has been a decrease in the amount of rice field land with subak as much 91 hectares and in the same year reduced again as much as 35 hectares. Even in the subsequent years the problem of land conversion and environmental problems in Denpasar due to migration seems increasingly complex.

Cases concerning the conversion of other irrigated agricultural land and the proliferation of construction of semi-permanent rented houses and slum settlements occurred throughout the sub-districts of Denpasar, including in East Denpasar sub-districts, slum dwellings and semi-permanent semi-permanent houses can be found in the area The village of Pakraman Yangbatu, a number of scavengers, built houses for residence mostly from used materials (zinc, cardboard, and gedeg) so that the settlement looked very shabby and damaged the image of Denpasar as the city of Culture. Similarly, a similar case was encountered in South Denpasar sub-district, among others found in the suburban neighborhood of Graha Santi, Sidakarya Sub-district adjacent to Sesetan Village, where slum settlements and semi-permanent buildings lined up along the river are quite disturbing image of Denpasar as a city culture.

\section{CONCLUSION}

Based on the above discussion can be concluded, first, the characteristics of average age of migrants classified as productive, is in the range 30-40 years (> 50\%). The level of education of migrants is quite good, most are highschooler and even some university-educated respondents. This condition will certainly be a threat to the local population in the competition seize job opportunities in the future. Driving factors and attracting the increase of migration intensity in Denpasar, among others: (1) 
economic motivation of migrant population; (2) security and comfort of Denpasar, and (3) adequate facilities become dominant attraction

The model of cultural adaptation of migrant population and its implications on socio-cultural and environmental in Denpasar, that non-Hindu residents have a tendency more difficult to adapt to the local population due to ethnic, religious and cultural differences. Therefore, the adaptation tends to choose clustering based on ethnic background similarity, origin and religion. In addition, administrative and physical adaptation is also done with the motivation to get legal protection and comfort in economic activity.

The social implication of migration culture in Denpasar is the formation of a multi-ethnic, multi-cultural and multireligious city of Denpasar, but tolerance and harmonization of relationships among them are still in good condition. That is, multiculturalism in Denpasar is a social cultural reality is running well but must continue to be managed to maintain social harmony in a sustainable manner. Social implications related to economic activity of dynamics and competition or seizure of economic resources between local people and migrants, especially in the informal sector. In the informal sector, the dominance of migrants appears to be stronger, even in certain areas of staple food (food) of local people becoming increasingly dependent on migrants. Implications in the field of culture, local culture have not changed significantly. However, the environmental implications appear to be significant, namely the conversion of agricultural land to the function of housing and other economic estalase in line with the increasing population of migrants in Denpasar who need shelter. The proliferation of slum settlements in the pockets of migrant communities throughout the subdistrict in Denpasar, and the declining quality of the well water of the population due to the domestic waste of migrant population and more liquid than industrial activities such as garment and loundry services. On the phenomenon, it can be suggested to the Mayor and the entire ranks of Denpasar Government to make the control of migrant population as the priority scale of development, as it has the potential to generate significant social, political and environmental impacts.

\section{REFERENCES}

[1] Afifuddin, H, dan Beni Ahmad Saebani. 2009. Metodologi Penelitian Kualitatif. Bandung: Pustaka Setia.

[2] Agger, Ben. 2003. Teori Sosial Kritis: Kritik, Penerapan, dan Implikasinya. Yogyakarta: Kreasi Wacana.

[3] Anderson, Benedict, 1999. Komunitas-Komunitas Terbayang Renungan Tentang Asal Usul dan Penyebaran Nasionalisme. Alih Bahasa Omi Intan Naomi. Yogyakarta: Pustaka Pelajar.

[4] Astra, I Gde, Semadi, dkk. 2003. Guratan Budaya dalam Perspektif Multi Kultural. Denpasar : Kerja sama Program Studi Magister dan Doktor Kajian Budaya, Linguistik, dan Jurusan Antropologi, Fakultas Sastra dan Budaya Universitas Udayana, dan CV Bali Media.

[5] Atmadja, Nengah Bawa, 2005, "Bali Pada Era Globalisasi: Pulau Seribu Pura Tidak Seindah Penampilannya" (hasil penelitian - studi kasus pada berbagai desa), Singaraja:-

[6] Ayatrohaedi.ed.1986. Kepribadian Budaya Bangsa (Lokal Genius), Jakarta. Pustaka Jaya.
[7] Baidhawy, Zakiyudin. 2002. Ambivalensi Agama Konflik \& Nirkekerasan. Yogyakarta: LESFI.

[8] Balipost, edisi 09 Agustus 2011. "Perda Kependudukan Sering Dilanggar".

[9] Bappeda Kota Denpasar. 2012. Denpasar Dalam Angka Tahun 2015.Denpasar: Pemerintah Kota Denpasar.

[10] Bennet, John. 1976. The Ecological Transition, Cultural Anthropology \& Human Adaptation. New York: Pergamon Press.

[11] Berger-Schmitt. 2000. Social Cohesion as an Aspect of the Quality of Societies: Concept and Measurement.EuReporting Working Paper No 14.

[12] Budiman, Hikmat (ed). 2005. Hak Minoritas Dilema Multikulturisme di Indonesia. Jakarta: Yayasan Interseksi/The Interseksi Foundation.

[13] Campbell, Tom. 1994. Tujuh Teori Sosial: Sketsa, Penilaian, Perbandingan. Yogyakarta: Kanisius.

[14] Colletta, Nat J., Teck Ghee Lim, Anita Kelles-Viitanen. 2001. Social Cohesion and Conflict Prevention inAsia: Managing Diversity through Development. Washington D.C.: The World Bank.

[15] Daeng, Hans J. 2008. Manusia, Kebudayaan, dan Lingkungan Tinjauan Antropologis. Yogyakarta: Pustaka Pelajar.

[16] Departemen Pendidikan Nasional. 2005. Kamus Besar Bahasa Indonesia. Jakarta: Balai Pustaka.

[17] Ellen, Roy. 1982. Environment, Subsistence, \& System. New York: Cambridge University Press.

[18] Garna, Judistira K. 1992. Teori-Teori Perubahan Sosial. Bandung: Program Pasca Sarjana Universitas Padjadjaran.

[19] Geriya, I Wayan. 2000. Transformasi Kebudayaan Bali Memasuki Abad XXI. Denpasar: Dinas Kebudayaan Propinsi Bali.

[20] Gunadha, Ida Bagus. 2009. Strategi Pemberdayaan Adat, Budaya, dan Agama Hindu Bali. Denpasar: Program Magister Ilmu Agama dan Kebudayaan, UNHI Denpasar.

[21] Hardestry, Richard W. 1977. Ecological Anthropology. New York: John Wiley \& Suns.

[22] Kaplan, David \& Robert.A. Manners. 2002. Teori Kebudayaan. Jakarta: Pustaka Pelajar.

[23] Liliweri, Alo.2005. Prasangka dan Konflik, Komunikasi Lintas Budaya Masyarakat Multikultur. Yogyakarta: LkiS.

[24] Miles \& Huberman.A. 1992. Analisis Data Kualitatif. Jakarta: Universitas Indonesia.

[25] Mulyana, Deddy. 2001. Metodologi Penelitian Kualitatif Paradigma Baru Ilmu Komunikasi dan Ilmu Sosial Lainnya. Bandung: Remaja Rosdakarya.

[26] Nawawi, H. Hadari. 2007. Metode Penelitian Bidang Sosial. Yogyakarta: Gadjah Mada University Press.

[27] Nurkhoiron, M. 2007. "Minoritisasi dan Agenda Multikulturalisme di Indonesia: Sebuah Catatan Awal", dalam Hak Minoritas Multikulturalisme dan Dilema Negara Bangsa. Editor: Marsudi Noorsalim, dkk. Jakarta: Yayasan Interseksi/The Interseksi Foundation.

[28] Parekh, Bhiku. 2007. Rethinking Multikulturalism Keberagaman Budaya dan Teori Politik. Yogyakarta: Kanisius.

[29] Poerwanto, Heri. 2008. Kebudayaan dan Lingkungan dalam Perspektif Antropologi. Yogyakarta: Pustaka Pelajar.

[30] Ritzen et al. 2000. "Good"Politicians and "Bad" Policies: Social Cohesion,Institutions and Growth. World Bank. Jo Ritzen,William Easterly, dan Michael Woolcock (September) Policy Research Working Paper 2448.

[31] Ritzer, George \& Goodman, Douglas J. 2003. Teori Sosiologi Modern. Jakarta: Prenada Media.

[32] Sahlins, Marshall.1976. Culture and Practice Reaseon. Chicago: University of Chicago Press.

[33] Sanderson, Stephen K. 2003. Makro Sosiologi, Sebuah Pendekatan Terhadap Realitas Sosial. Jakarta: PT. RajaGrafinfdo Persada.

[34] Siddique, Sharon, 2001. "Social Cohesion and Social Conflict in Southeast Asia" dalam "Social Cohesion and Conflict Prevention in Asia: Managing Diversity through Development" Washington D.C.: The World Bank.

[35] Soekanto, Soerjono. 2004. Sosiologi: Suatu Pengantar. Jakarta: PT. Raja Grafindo Persada.

[36] Soetrisno, L. 2003. Konflik Sosial Studi Kasus Indonesia. Yogyakarta: Tajidu Press.

[37] Suaedy, Ahmad, dkk. 2007. Politisasi Agama dan Konflik Komunal Beberapa Isu Penting di Indonesia. Jakarta: The Wahid Institute. 
[38] Sutopo dan Adi Suryanto. 2006. Pelayanan Prima. Jakarta: Lembaga Administrasi Negara Republik Indonesia.

[39] Suyanto, Bagong dan Sutinah (editor). 2005. Metode Penelitian Sosial: Berbagai Alternatif Pendekatan. Jakarta: Prenada Media.

[40] Tilaar, H.A.R.2004. Multikulturalisme Tantangan-tantangan Global Masa Depan dalam Transformasi Pendidikan Nasional. Jakarta: Grasindo.

[41] Tim Penyusun. 2008. Selayang Pandang Kota Denpasar Tahun 2008. Denpasar: Pemerintah Kota Denpasar.

[42] Zuriah, Nurul. 2005. Pendidikan Moral dan Budi Pekerti dalam Prespektif Perubahan. Jakarta. Bumi Aksa 